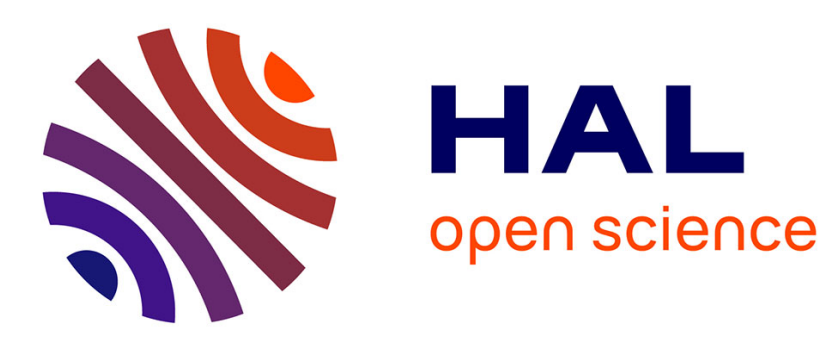

\title{
Early stages of compressive plastic deformation of asymmetrical bicrystal
}

J. Gemperlová, P. Šittner, V. Paidar

\section{To cite this version:}

J. Gemperlová, P. Šittner, V. Paidar. Early stages of compressive plastic deformation of asymmetrical bicrystal. Revue de Physique Appliquée, 1988, 23 (4), pp.684-684. 10.1051/rphysap:01988002304068400 . jpa-00245833

\section{HAL Id: jpa-00245833 https://hal.science/jpa-00245833}

Submitted on 1 Jan 1988

HAL is a multi-disciplinary open access archive for the deposit and dissemination of scientific research documents, whether they are published or not. The documents may come from teaching and research institutions in France or abroad, or from public or private research centers.
L'archive ouverte pluridisciplinaire HAL, est destinée au dépôt et à la diffusion de documents scientifiques de niveau recherche, publiés ou non, émanant des établissements d'enseignement et de recherche français ou étrangers, des laboratoires publics ou privés. 


\author{
EARLY STAGES OF COMPRESSIVE PJASTIC \\ DEFORMATION OF ASYMMETRICAI BICRYSTAL \\ J. Gemperlová, P. Śittner, V. Paidar \\ Institute of Physics, Czechosl. Acad. Sci. \\ Na Slovance 2, 18040 Praha 8, CSSR
}

Plastic deformation of polycrystals is essentially affected by the additional stresses which arise as a consequence of compatibility requirements on the grain boundaries. The additional stresses depend on the elastic constants, geometrical characteristics and plastic deformation of the crystalline grains. Because of a large number of parameters it is necessary and useful to analyse these stresses in bicrystals.

The additional stresses will be theoretically assessed for the model where the bicrystal is made from two half-spaces which are homogeneously deformed. Iocalization and inhomogeneity of plastic deformation are not taken into account. The results will be described in more details for the case of $\Sigma=5$ cubic bicrystal with the rotation axis $[\overline{100}]$ and the misorientation angle of $37^{\circ}$. The normal of the grain boundary plane bisects the angle between the normals to the symmetrical orientations of the boundary on the $\{013\}$ and $\{012\}$ planes. The effect of compatibility stresses for this orientation has a maximum whereas the symmetrical bicrystals are fully compatible and no additional stresses are induced. The results of calculations of stresses resolved on 4 slip systems in each grain will be compared with observations of slip patterns both on free surfaces and on $\{100\}$ cuts after dislocation etching. For the Fe-6at\% 1 b.c.c. alloy, all possible slip systems with the $\langle 111\rangle$ slip directions and the slip planes identical with corresponding planes of maximum resolved shear stress were considered. The additional stresses increase with the angle $\alpha$ between the stress and rotation axes. They can cause the activation of slip in the grain with lower Schmid factor, but also they can prevent the activation of slip in the grain with higher Schmid factor. Both effects have been observed experimentally. Preliminary theoretical results on compatibility stresses in the model where the elastic anisotropy in component crystals is fully taken into account is presented in $[1]$. The calculated dependences of the resolved shear stresses, $\tau$, on $\alpha$ are plotted for an infinite bicrystal with boundary planes close to $(0114)$ in $A$ grain and $(02023)$ in B grain (the tilt axis has $[\overline{100}]$ direction). The full line represents the total maximum shear stress resolved in the [111] slip direction in the $A$ grain and in the [11\%] in the $B$ grain. The dashed line corre- sponds to the respective maximum resolved shear stress calculated for the applied. stress, $\sigma$, only. For example for $\alpha=80^{\circ}$

the $[\overline{1} 1 \overline{1}]$ slip system has the highest Schmid factor in the B grain while there are two slip system [111] and [1\%1], in the A grain with comparable Schmid factors due to the applied stress $a$ only. When the additional compatibility stresses are taken into account the total resolved shear stress in the A grain is reduced for both systems and the resolved shear atress for the [ $\overline{1} 1 \overline{1}]$ slip system in the $B$ grain is raised. In spite of the fact that the maximum resolved shear stress due to the applied stress in the $A$ grain is higher than in the B grain, the slip in the A grain has not been activated. It was observed experimentally that the slip was activated in the $B$ grain where it occured in the $[\overline{1} 1 \overline{1}]$ direction.
A GRAIN

[111] slip systems

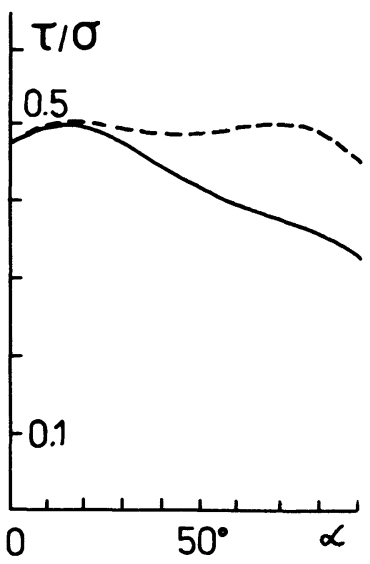

In the erame of isotropical theory of elasticity the problem of additional compatibility stresses caused by different plastic deformation in the grain $A$ and $B$ was studied in [2].

\section{References :}

1 J. Gemperlová, V. Paidar: Czech. J. Phys. B 35 (1985), 351

2 C. Rey, A. Zaoui: Acta Metall. 28 